\title{
Mode shifting in school travel mode: examining the prevalence and correlates of active school transport in Ontario, Canada
}

\author{
Bonny Yee-Man Wong ${ }^{1 *}$, Guy Faulkner ${ }^{1}$, Ron Buliung ${ }^{2}$ and Hyacinth Irving ${ }^{3}$
}

\begin{abstract}
Background: Studies examining the correlates of school transport commonly fail to make the distinction between morning and afternoon school trips. The purpose of this study was to examine the prevalence and correlates of mode shift from passive in the morning to active in the afternoon among elementary and secondary school students in Ontario, Canada.

Methods: Data were derived from the 2009 cycle of the Ontario Student Drug Use and Health Survey (OSDUHS). 3,633 students in grades 7 through 12 completed self-administered questionnaires. Socio-demographic, behavioural, psychological, and environmental predictors of active school transport (AST) were assessed using logistic regression.

Results: Overall, $47 \%$ and $38 \%$ of elementary school students reported AST to and from school, respectively. The corresponding figures were $23 \%$ and $32 \%$ for secondary school students. The prevalence of AST varied temporarily and spatially. There was a higher prevalence of walking/biking found for elementary school students than for secondary school students, and there was an approximate 10\% increase in AST in the afternoon. Different correlates of active school transport were also found across elementary and secondary school students. For all ages, students living in urban areas, with a shorter travel time between home and school, and having some input to the decision making process, were more likely to walk to and from school.

Conclusions: Future research examining AST should continue to make the analytic distinction between the morning and afternoon trip, and control for the moderating effect of age and geography in predicting mode choice. In terms of practice, these variations highlight the need for school-specific travel plans rather than 'one size fits all' interventions in promoting active school transport.
\end{abstract}

\section{Background}

Given the increasing trend of obesity and decline in physical activity in children and youth [1], the journey to and from school presents one source of energy expenditure through the use of non-motorized travel modes such as walking or biking. Children and youth who practice active school transport (typically walking or cycling) have been consistently found to be more physically active overall than children who do not [2]. However, studies consistently report decreasing prevalence of active school transport (AST) [3]. For example,

\footnotetext{
* Correspondence: bonnyym.wong@utoronto.ca

${ }^{1}$ Faculty of Physical Education \& Health, University of Toronto, 55 Harbord

Street, Toronto, Ontario, M5S 2W6, Canada

Full list of author information is available at the end of the article
}

in the Greater Toronto Area, Canada's largest city-region, the prevalence of walking as the usual mode to school decreased from 1986 to 2001 (53\% to $42 \%$ for children aged $11-13,39 \%$ to $31 \%$ for children aged 14-15) [4].

Identifying the prevalence and correlates of active school transport is important for the development of interventions aimed at promoting AST and future surveillance and monitoring of policy effectiveness. Reviews of the literature identify the broad range of correlates of AST that have been studied and highlight that findings are commonly mixed. This is probably due to the heterogeneity of populations and locations being studied [3]. That is, the importance of certain correlates may vary based on geographic location and age group of the
C Biomed Central

(c) 2011 Wong et al; licensee BioMed Central Ltd. This is an Open Access article distributed under the terms of the Creative Commons Attribution License (http://creativecommons.org/licenses/by/2.0), which permits unrestricted use, distribution, and reproduction in any medium, provided the original work is properly cited. 
population being studied. There have been at least four studies on AST among Canadian children and youth [5-8]. In terms of socio-demographic factors, girls $[5,7,8]$, students with lower socio-economic status [9], and older students [7-9] were consistently found to be less likely to walk or cycle to school.

Only one Canadian study has examined psychological correlates of AST, finding no association between perceived athletic ability, perceived parent encouragement, and perceived weight status and AST [8]. Of growing interest is the concept of childhood independent mobility. Independent mobility is defined as the 'opportunity for children to move around independently without adults as escorts' [10]. Independent mobility is of interest because children with greater independent mobility may spend more time outdoors being physically active [11]. Autonomy with respect to mobility decisions and outcomes has been found to be an important psychological factor impacting on school transport [11-16]. For example, youth who reported their parents knew little or nothing about their whereabouts after school were more likely to actively commute to school [13]. Notably, the impact of whether children and youth are involved in the process of decision-making (which may reflect both independence and motivation for walking) on school transport mode has not been studied.

For the behavioural correlates of active school transport, children and youth who actively travelled to school were consistently found to be more physically active regardless of age, gender, and country [8]. Environmental factors also may play an important role in school transport. Canadian studies have found that youth living in urban areas $[7,8]$ and within a shorter distance to school were more likely to actively commute to school $[5,6]$. These findings are also consistent with international research [3,17]. Moreover, regional differences in active school transport have been consistently reported $[18,19]$.

More broadly, within the school transport literature internationally, separate analyses for school mode choice in the morning and afternoon has not been a common practice. For example, in the comprehensive review by Sirard and Slater [3], this distinction is not explicitly discussed. In a recent systematic review on the built environment and active school travel, only five out of 14 studies analysed school mode choice in the a.m. and p. $\mathrm{m}$. periods separately [20]. Recent research highlights the importance of making such a distinction [6]. Importantly, no study has examined the correlates of the most common mode shift - shifting from passive modes of travel in the morning to active modes of travel in the afternoon $[3,20]$. It is important to identify these mode shifters since promoting active school transport may be more feasible for these individuals than those being driven both ways. These parents or other caregivers already allow their children to take at least one trip actively. Identifying who these students are may also be helpful in the consideration of interventions that specifically target the a.m. or p.m. period. Apart from some exceptions [21], the prevalence and correlates of both elementary and secondary school students have not commonly been analysed separately. Existing studies $[5,7,8]$ have also relied on convenience samples for their analyses. To address these gaps, the present study uses a provincially representative sample of elementary and secondary school students in Ontario, Canada to examine the following two questions: i) what is the prevalence, and the correlates of school travel mode to school and back home and ii) what are the correlates associated with the school travel choices of students who shift from passive to active modes between the a.m. and p.m. school travel time periods.

\section{Methods}

\section{Subjects and procedures}

Three thousand and six hundred students in grades 7 to 12 in Ontario completed the 2009 cycle of the Ontario Student Drug Use and Health Survey (OSDUHS), a selfadministered, anonymous questionnaire, during a class period. The OSDUHS is a repeated cross-sectional survey conducted every two years by the Centre for Addiction and Mental Health, Toronto, Canada, to assess the health behaviours of youth in Ontario. These respondents were selected using a stratified two-stage cluster sampling method that used representative sampling of all grade 7 to 12 students in publicly funded schools in Ontario. Stratified by school type (elementary and secondary school) and by region $(n=4$; Toronto; Northern Ontario [Parry Sound District, Nipissing District and farther north]; Western Ontario [Hamilton, Peel District, Dufferin County and farther west]; and Eastern Ontario [Ottawa, Leeds-Grenville-Lanark District, HaliburtonKawartha-Pine Ridge District, Simcoe County, Durham Region, and York Region]), schools were randomly selected first, followed by a random selection of classes of each grade within each selected school. Of the 14,196 students enrolled in selected classes, 9,241 participated in the survey. The student participation rate was $65 \%$ (13\% absenteeism and 22\% unreturned consent forms or parents' refusal). One hundred and twenty-nine respondents were dropped from the dataset, due to failure to report valid responses for age or sex, or because they did not complete at least half of the questionnaire $(9,112$ included). Of these 9,112 cases, 1,533 elementary students (Grade 7 and 8) and 2,728 secondary (Grade 9 to 12) completed Form B questionnaires that included questions about school transport developed by the authors. One hundred fifty-seven elementary school students did not complete at least half of the school 
transport section and hence were excluded $(1,376$ included). Elementary school students had difficulty in providing information on parental education (19.5\% missing data), their anthropometric measures (8.8\%), and postal code of their residence (6.5\%). However, included and excluded subjects were comparable in terms of sex, grade and regions (Cohen's d [22] $=0.12$ for sex, 0.15 for grade and 0.09 for regions). Cases in which neither parent's education was available $(n=268$ elementary and $n=198$ secondary) were recoded to the sample mean of 14.5 years. This construct was developed using an approach similar to that used in previous research [23-25]. After substituting missing data on years of parent's education with the mean value, among 1,376 and 2,728 elementary and secondary students, $1,086(78.9 \%)$ and 2,479 (90.9\%) elementary and secondary school students had complete data which was used for addressing the first objective. For the second objective, among 1,086 and 2,479 elementary and secondary school students from the first objective, 741 (61.6\%) and $1,960(77.2 \%)$ who did not walk/bike to school in the morning were included. Among students included in the second objective, 102 elementary and 272 secondary school students shifted their travel mode from passive in the morning to active in the afternoon. Ethical approval for the study was granted by the institutional research ethics committees at CAMH, York University, as well as at eleven Ontario district school boards.

\section{Instruments}

\section{School transport}

Travel mode to school in the morning and from school in the afternoon was assessed separately. Respondents were asked 'how do you usually travel i) to and ii) from school?' School transport modes for the morning and afternoon were reclassified into a categorical variable with two categories: walking/biking and other. This mirrors the practice in much of the literature to examine travel behaviour across a broad classification of active and passive travel modes [3]. Mode shifters were defined as those not walking to school in the morning but walking back home in the afternoon.

\section{Correlates}

Socio-demographic (eight variables), behavioural (six variables), psychological (four variables), and environmental (seven variables) correlates were assessed $(n=25$ in total).

\section{Socio-demographic}

Demographic variables such as sex and grade (Grade 7 to 12) were examined. BMI was computed based on self-reported height and weight. The weight status (normal, overweight and obese) was defined according to age- and sex-specific international BMI (IOTF) cut-offs [26]. Years of highest parental education, a socio- economic status indicator, was assessed considering paternal and maternal education. Parents' place of birth and having a sibling(s) were also assessed. With respect to the transportation context, driver licensing and number of household cars were examined.

\section{Behavioural}

Students were asked 'On how many of the last seven days were you physically active for a total of at least $60 \mathrm{~min}$ utes each day?' Examples such as brisk walking, soccer, swimming were given. The Centers for Disease Control and Prevention (CDC) physical activity recommendation for adolescents [27] is at least 60 minutes of MVPA on most days of the week. In the context of active school transport, physical activity levels over five school days may be more relevant. Therefore, Moderate to Vigorous Physical Activity (MVPA) was classified as zero to four days, and five days or more. Self-reported screen-time was based on the current recommendation of 2 hours or less of screen time daily [28] and grouped as 2 hours per day or less, and more than 2 hours per day.

To examine whether there were other behavioural correlates of active school transport, smoking in the past 12 months was asked and categorised as non-smokers (never in lifetime)/smoked but not in past 12 months) and smokers (a few puffs to a whole cigarette everyday). Drinking in the past 12 months was categorised as non-drinkers (never/drank but not in past 12 months) and drinkers (just had a sip of alcohol to see what it's like to almost everyday).

Working part-time and participation in extracurricular activities may incur a time cost and reduce the likelihood of active school transport. Moreover, students and their households may have other destinations than home in the morning or afternoon that may affect school travel mode choice. Extracurricular participation was categorised as yes and no. For secondary students, working part-time was grouped as 'don't work for pay outside home,' 5 hours/week or less, and 6 hours/week or more.

\section{Psychological}

To measure perceived weight status, respondents were asked 'do you think of yourself as being too thin, about the right weight, or too fat?'. Perceived physical health was measured by asking 'how would you rate your physical health?' with options of excellent, very good, good, fair, and poor and re-grouped into excellent/very good/ good and fair/poor.

The extent of parental supervision was asked with the question, 'In your free time away from home, how often does at least one of your parents know where you are?'. Responses were regrouped as never/rarely/sometimes and often/always. The question of autonomy with respect to school travel was addressed by asking, 'How often do you get to decide how you travel to school and 
back home'. Responses were reclassified as never/rarely/ sometimes and often/always.

\section{Environmental}

Travel time to school and from school were measured separately and categorised as 0-15 minutes, 16-30 minutes and 31 minutes or more. Longer travel time implies longer distance, greater cost (in terms of temporal value), and more effort required for each mode. The same travel time implies greater (physical) effort required for active compared to passive modes (e.g., more physical effort required for walking for an hour than driving/being driven for an hour) and longer travel distance for passive than active modes. Given that parental decision on their child's school travel mode mainly is based on convenience [29], travel time may be an important correlate of school travel. The likelihood of an active school travel mode is hypothesized to decrease with travel time whereas the likelihood of a passive mode is hypothesized to increase with travel time.

Moving home or changing school in the past five years was modeled categorically; residential mobility may act as a latent indicator of neighbourhood familiarity (i.e., familiarity produces active travel). Other environmental characteristics included living in an urban or rural area (based on postal codes) and school affiliation (catholic or no religion) which has been suggested as a correlate of AST [15]. Differences in religious affiliation may be a broader indicator of a difference in school transport policy between different school boards. Regional variation in AST was also examined.

\section{Data analysis}

All analyses used Taylor series methods to account for the complex survey design. Logistic regression was used to identify the correlates of active school transport separately for the morning and afternoon and for students who mode shifted from passive in the morning to active in the afternoon. Two models were created: i) unadjusted models where the effects of each variable on active school transport or mode shift were examined separately and ii) fully adjusted models where only significant correlates in the unadjusted models were included. Physical activity and weight status as well as demographic (grade and sex) variables were included in all models. All analyses were stratified by elementary and secondary school students due to potential differences in independence, availability and use of travel modes, and correlates [17]. All analyses were conducted using Stata 11.

\section{Results}

Tables 1 and 2 summarize the descriptive information for the sample and the prevalence of active school
Table 1 Descriptive statistics for elementary and secondary school students

\begin{tabular}{|c|c|c|c|}
\hline & $\begin{array}{l}\text { Elementary } \\
\text { n (\%) }\end{array}$ & $\begin{array}{l}\text { Secondary } \\
\mathrm{n}(\%)\end{array}$ & p-value \\
\hline \multicolumn{4}{|l|}{ Socio-demographic } \\
\hline \multicolumn{4}{|l|}{ Grade } \\
\hline Grade 7 & $506(48.2)$ & & - \\
\hline Grade 8 & $583(51.8)$ & & \\
\hline Grade 9 & & $590(21.6)$ & \\
\hline Grade 10 & & $654(23.4)$ & \\
\hline Grade 11 & & $597(24.3)$ & \\
\hline Grade 12 & & $638(30.8)$ & \\
\hline Sex (female) & $604(48.2)$ & $1272(47.9)$ & 0.91 \\
\hline Weight status (overweight/obese) & $241(26.7)$ & $620(24.8)$ & 0.42 \\
\hline $\begin{array}{l}\text { Years of highest parent education } \\
\text { (yrs) (mean(SD)) }\end{array}$ & $14.6(1.6)$ & $14.5(1.7)$ & 0.17 \\
\hline Parent born abroad (yes) & $229(32.2)$ & $719(33.0)$ & 0.83 \\
\hline Having sibling (yes) & $1011(92.8)$ & $2328(93.9)$ & 0.44 \\
\hline Having car at home (yes) & $1053(95.6)$ & $2424(97.0)$ & 0.13 \\
\hline Having driver license (yes) & - & $1046(42.2)$ & - \\
\hline \multicolumn{4}{|l|}{ Behavioural } \\
\hline MVPA ( $\geq 5$ days/wk) & $568(53.9)$ & $1105(42.6)$ & $<0.001$ \\
\hline Screen time (> 2 hours/day) & $539(49.6)$ & $1518(61.2)$ & $<0.001$ \\
\hline $\begin{array}{l}\text { Smoking in the past } 12 \text { months } \\
\text { (occasional/regular smokers) }\end{array}$ & $49(5.3)$ & $572(22.4)$ & $<0.001$ \\
\hline $\begin{array}{l}\text { Drinking in the past } 12 \text { months } \\
\text { (occasional/regular drinkers) }\end{array}$ & $567(52.1)$ & $1962(78.8)$ & $<0.001$ \\
\hline \multicolumn{4}{|l|}{ Part-time job } \\
\hline Did not work outside home & - & $1302(53.5)$ & - \\
\hline 1-5 hours/wk & - & $301(11.2)$ & \\
\hline$\geq 6$ hours/wk & - & $876(35.3)$ & \\
\hline Extracurricular participation (yes) & $838(77.6)$ & $1755(70.8)$ & 0.06 \\
\hline \multicolumn{4}{|l|}{ Psychological } \\
\hline $\begin{array}{l}\text { Perceived physical health } \\
\text { (excellent/good) }\end{array}$ & $74(7.6)$ & $400(17.7)$ & $<0.001$ \\
\hline \multicolumn{4}{|l|}{ Perceived weight status } \\
\hline About right & $779(73.9)$ & $1699(65.9)$ & $<0.001$ \\
\hline Too thin & $84(6.3)$ & $218(10.2)$ & \\
\hline Too fat & $216(19.8)$ & $555(23.9)$ & \\
\hline $\begin{array}{l}\text { Decision-making on mode choice } \\
\text { (often/always) }\end{array}$ & $340(3.1 .5)$ & $956(40.4)$ & 0.001 \\
\hline $\begin{array}{l}\text { Parents don't know where their } \\
\text { children are in free time away } \\
\text { from home (sometimes/seldom/ } \\
\text { never) }\end{array}$ & $74(7.9)$ & $348(15.9)$ & $<0.001$ \\
\hline \multicolumn{4}{|l|}{ Environmental } \\
\hline \multicolumn{4}{|l|}{ Travelled to school } \\
\hline 0-15 minutes & $708(68.3)$ & $1570(63.5)$ & 0.13 \\
\hline 16-30 minutes & $210(18.7)$ & $552(23.9)$ & \\
\hline$\geq 31$ minutes & $168(13.0)$ & $357(12.6)$ & \\
\hline \multicolumn{4}{|l|}{ Travelled from school } \\
\hline 0-15 minutes & $646(61.4)$ & $1202(48.4)$ & $<0.001$ \\
\hline $16-30$ minutes & $253(22.7)$ & $738(30.6)$ & \\
\hline$\geq 31$ minutes & $184(16.0)$ & $533(20.9)$ & \\
\hline Living in urban area (urban) & $857(84.7 .0)$ & $2075(83.7)$ & 0.86 \\
\hline
\end{tabular}


Table 1 Descriptive statistics for elementary and secondary school students (Continued)

\begin{tabular}{|c|c|c|c|}
\hline \multicolumn{4}{|l|}{ Regions } \\
\hline Toronto & $112(21.6)$ & $256(16.6)$ & 0.07 \\
\hline North & $57(5.7)$ & $199(6.6)$ & \\
\hline West & $304(43.9)$ & $857(43.6)$ & \\
\hline East & $613(28.9)$ & 1167 (33.2) & \\
\hline Catholic school (yes) & $376(38.9)$ & 935 (36.4) & 0.80 \\
\hline $\begin{array}{l}\text { Changing school in the last five } \\
\text { years (yes) }\end{array}$ & 419 (43.5) & $752(30.2)$ & $<0.001$ \\
\hline $\begin{array}{l}\text { Moving home in the last five years } \\
\text { (yes) }\end{array}$ & $513(48.5)$ & $1031(44.5)$ & 0.24 \\
\hline
\end{tabular}

transport. The overall prevalence of active school transport ranged from $38 \%$ in the morning to $47 \%$ in the afternoon among elementary school students. The corresponding figures were $23 \%$ and $32 \%$ for secondary school students. The lowest prevalence of walking/biking to and from school in elementary school students were $23 \%$ in Northern Ontario and 30\% in Eastern Ontario, respectively, whereas the greatest proportions were $60 \%$ and $68 \%$ in Toronto, correspondingly. The prevalence of walking/biking to and from school in secondary school students ranged from $20 \%$ and $24 \%$ in the North to $30 \%$ and $39 \%$ in Toronto, respectively. Among secondary students in the sample, $42.2 \%$ held a drivers license, considerable potential exists for secondary students to drive alone or with others either to or from school.

Among elementary school students, more years of parental education $\left(\mathrm{OR}_{\mathrm{to}}=0.83 ; 95 \% \mathrm{CI}\right.$ : $0.75-0.92$ and $\left.\mathrm{OR}_{\mathrm{fr}}=0.86 ; 95 \% \mathrm{CI}: 0.78-0.96\right)$, longer travel time $\left(\mathrm{OR}_{\text {to16-30 m }}=0.40 ; 95 \%\right.$ CI: $0.20-0.80, \mathrm{OR}_{\mathrm{to} \geq 31 \mathrm{~m}}=0.11$; 95\% CI: 0.03-0.32, OR fr16-30 $\mathrm{m}=0.45$; 95\% CI: 0.25-0.81, and $\left.\mathrm{OR}_{\mathrm{fr} \geq 31 \mathrm{~m}}=0.40,95 \% \mathrm{CI}: 0.19-0.85\right)$, and living in the North $\left(\mathrm{OR}_{\mathrm{to}}=0.27 ; 95 \% \mathrm{CI}: 0.10-0.70\right.$ and $\mathrm{OR}_{\mathrm{fr}}=$ 0.31; 95\% CI: 0.10-0.98) were negatively correlated with walking/biking either to or from school whereas living in urban areas was positively correlated with walking/ biking either to or from school $\left(\mathrm{OR}_{\mathrm{to}}=3.00 ; 95 \% \mathrm{CI}\right.$ : 1.29-6.98 and $\mathrm{OR}_{\mathrm{fr}}=4.84 ; 95 \%$ CI: 2.05-11.42) (Table 3). Physical activity $\left(\mathrm{OR}_{\mathrm{to}}=1.27 ; 95 \%\right.$ CI: $0.95-1.71$ and
$\mathrm{OR}_{\mathrm{fr}}=0.90 ; 95 \%$ CI: 0.59-1.36) and weight status $\left(\mathrm{OR}_{\mathrm{to}}=\right.$ 0.83; 95\% CI: $0.60-1.33$ and $\mathrm{OR}_{\mathrm{fr}}=0.90$; 95\% CI: 0.59 1.36) were not associated with walking/biking to or from school. Better perceived health and being involved in the school travel decision making process were only correlated positively with active school transport in the afternoon $\left(\mathrm{OR}_{\mathrm{ph}}=2.20 ; 95 \% \mathrm{CI}: 1.23-3.92\right.$ and $\mathrm{OR}_{\text {decide }}=$ 1.73; 95\% CI: 1.11-2.69, respectively). In contrast, the presence of a household car was negatively correlated with active school transport in the morning $\left(\mathrm{OR}_{\mathrm{to}}=\right.$ 0.22; 95\% CI: 0.08-0. 61).

Table 4 shows the correlates of active school transport for secondary school students. Female students $\left(\mathrm{OR}_{\mathrm{to}}=\right.$ 0.66; 95\% CI: $0.49-0.89$ and $\mathrm{OR}_{\mathrm{fr}}=0.74 ; 95 \% \mathrm{CI}: 0.55$ $0.99)$ and those working part-time $\left(\mathrm{OR}_{\mathrm{to} \geq 6 \mathrm{hr} / \mathrm{wk}}=0.65\right.$; 95\% CI: $0.45-0.93$ and $\mathrm{OR}_{\mathrm{fr} \geq 6 \mathrm{hr} / \mathrm{wk}}=0.62$; $95 \% \mathrm{CI}: 0.44-$ $0.86)$ were less likely to actively commute to school in either the morning or afternoon. Living in an urban area $(\mathrm{OR}=2.67 ; 95 \% \mathrm{CI}: 1.22-5.82)$ and contributing to the school travel decision was positively correlated with walking/biking from school $(\mathrm{OR}=1.52$; $95 \% \mathrm{CI}$ : 1.13 2.04). Adolescents who walked/biked to school were more physically active $(\mathrm{OR}=1.39 ; 95 \% \mathrm{CI}: 1.01-1.90)$, had shorter travel times $\left(\mathrm{OR}_{16-30} \mathrm{~min}=0.84 ; 95 \% \mathrm{CI}\right.$ : $0.59-1.19$ and $\mathrm{OR}_{\geq 31} \min =0.23$; 95\%CI: $\left.0.13-0.38\right)$, and had moved house in the past five years $(\mathrm{OR}=1.33$; $95 \%$ CI: 1.05-1.70). Self-reported weight status was not associated with either morning or afternoon school trips $\left(\mathrm{OR}_{\mathrm{to}}=0.99 ; 95 \% \mathrm{CI}: 0.74-1.33\right.$ and $\mathrm{OR}_{\mathrm{fr}}=0.94 ; 95 \% \mathrm{CI}$ : 0.70-1.27).

In terms of mode shift, both elementary and secondary school students who lived in urban areas $\left(\mathrm{OR}_{\text {ele }}=\right.$ 3.58; 95\%CI: $1.00-12.90$ and $\mathrm{OR}_{\mathrm{sec}}=3.24$; $95 \% \mathrm{CI}: 1.18$ $8.85)$ and decided on their school travel mode $\left(\mathrm{OR}_{\mathrm{ele}}=\right.$ 2.43; $95 \% \mathrm{CI}: 1.23-4.80$ and $\mathrm{OR}_{\mathrm{sec}}=2.42$; $95 \% \mathrm{CI}: 1.61-$ 3.63) were more likely to shift their travel mode from passive in the morning to active in the afternoon (Table 5). Among secondary school students, students with a shorter travel time to school were more likely to shift their mode from passive in the morning to active in the afternoon $\left(\mathrm{OR}_{16-30 \mathrm{~m}}=0.11 ; 95 \% \mathrm{CI}\right.$ : $0.03-0.40$ and $\left.\mathrm{OR}_{\geq 31 \mathrm{~m}}=0.07 ; 95 \% \mathrm{CI}: 0.02-0.29\right)$. Only elementary

Table 2 Prevalence of active school transport in Ontario

\begin{tabular}{|c|c|c|c|c|c|c|c|c|}
\hline & \multicolumn{4}{|l|}{ Secondary } & \multicolumn{4}{|l|}{ Elementary } \\
\hline & To school & & From school & & To school & & From school & \\
\hline & Walk/bike & Other & Walk/bike & Other & Walk/bike & Other & Walk/bike & Other \\
\hline Toronto & $69(29.8)$ & $187(70.2)$ & 91 (38.9) & $165(61.1)$ & 65 (59.6) & $47(40.4)$ & 75 (68.4) & 37 (31.6) \\
\hline North & $46(20.0)$ & $153(80.0)$ & $53(24.0)$ & $146(76.0)$ & $11(22.6)$ & $46(77.4)$ & 18 (34.4) & 39 (65.6) \\
\hline West & $170(20.9)$ & $687(79.1)$ & $265(30.5)$ & $592(69.5)$ & $127(39.9)$ & $177(60.1)$ & $161(49.9)$ & $143(50.1)$ \\
\hline East & $234(22.5)$ & 933 (77.5) & 350 (31.5) & 817 (68.5) & $142(23.6)$ & $471(76.4)$ & 178 (29.7) & $435(70.3)$ \\
\hline \multirow[t]{2}{*}{ Total } & $519(22.9)$ & $1960(77.2)$ & 759 (31.8) & $1720(68.2)$ & $345(38.4)$ & 741 (61.6) & $432(47.2)$ & $654(52.8)$ \\
\hline & $p=0.18$ & & $p=0.27$ & & & $p==0.03$ & & $p=0.04$ \\
\hline
\end{tabular}


Table 3 Individual, behavioural, psycho-social, and environmental correlates of active school transports in elementary school students

\begin{tabular}{|c|c|c|c|c|c|c|c|c|}
\hline & \multicolumn{4}{|l|}{ To school } & \multicolumn{4}{|l|}{ From school } \\
\hline & Unadjusted OR & $95 \% \mathrm{Cl}$ & Adjusted OR & $95 \% \mathrm{Cl}$ & Unadjusted OR & $95 \% \mathrm{Cl}$ & Adjusted OR & $95 \% \mathrm{Cl}$ \\
\hline \multicolumn{9}{|l|}{ Socio- demographic } \\
\hline \multicolumn{9}{|l|}{ Grade } \\
\hline Grade 7 & 1 & & 1 & & 1 & & 1 & \\
\hline Grade 8 & 0.96 & $0.71-1.29$ & 0.83 & $0.59-1.16$ & 1.01 & $0.74-1.38$ & 0.95 & $0.65-1.38$ \\
\hline \multicolumn{9}{|l|}{ Sex } \\
\hline Boys & 1 & & 1 & & 1 & & 1 & \\
\hline Girls & 1.04 & $0.77-1.40$ & 1.00 & $0.72-1.37$ & 1.01 & $0.77-1.33$ & 0.85 & $0.59-1.23$ \\
\hline \multicolumn{9}{|l|}{ Weight status } \\
\hline Normal weight & 1 & & 1 & & 1 & & 1 & \\
\hline Overweight/Obese & 1.05 & $0.76-1.46$ & 0.83 & $0.60-1.33$ & 1.21 & $0.88-1.66$ & 0.90 & $0.59-1.36$ \\
\hline Years of highest parent education & $0.87^{* *}$ & $0.78-0.97$ & $0.83^{* *}$ & $0.75-0.92$ & $0.90^{*}$ & $0.82-0.99$ & $0.86^{* *}$ & $0.78-0.96$ \\
\hline \multicolumn{9}{|l|}{ Parent born abroad } \\
\hline Both/one parent born in Canada & - & - & & & 1 & & 1 & \\
\hline Both born abroad & - & - & & & $1.77^{*}$ & $1.06-2.97$ & 0.97 & $0.53-1.79$ \\
\hline \multicolumn{9}{|l|}{ Having car at home } \\
\hline No & 1 & & 1 & & 1 & & 1 & \\
\hline Yes & $0.20^{* * *}$ & $0.11-0.37$ & $0.22^{* *}$ & $0.08-0.61$ & $0.25^{* * *}$ & $0.12-0.50$ & 0.34 & $0.10-1.09$ \\
\hline \multicolumn{9}{|l|}{ Behavioural } \\
\hline \multicolumn{9}{|l|}{ MVPA } \\
\hline 0-4 day/wk & 1 & & 1 & & 1 & & & \\
\hline$\geq 5$ days/wk & 0.91 & $0.70-1.19$ & 1.27 & $0.95-1.71$ & 0.85 & $0.60-1.19$ & 1.19 & $0.77-1.84$ \\
\hline \multicolumn{9}{|l|}{ Psychological } \\
\hline \multicolumn{9}{|l|}{ Perceived physical health } \\
\hline Fair/poor & - & - & & & 1 & & 1 & \\
\hline Excellent/very good/good & - & - & & & $1.90^{*}$ & $1.11-3.24$ & $2.20^{*}$ & $1.23-3.92$ \\
\hline \multicolumn{9}{|l|}{ Decision-making on mode choice } \\
\hline $\begin{array}{l}\text { Never/rarely/ } \\
\text { sometimes }\end{array}$ & 1 & & 1 & & 1 & & 1 & \\
\hline Often/always & $1.70^{* *}$ & $1.18-2.46$ & 1.35 & $0.89-2.05$ & $2.04^{* * *}$ & $1.43-2.90$ & $1.73^{* *}$ & $1.11-2.69$ \\
\hline \multicolumn{9}{|l|}{ Environmental } \\
\hline \multicolumn{9}{|l|}{ Travelled to/from school } \\
\hline 0-15 minutes & 1 & & 1 & & 1 & & 1 & \\
\hline $16-30$ minutes & $0.38^{* * *}$ & $0.20-0.70$ & $0.40^{* *}$ & $0.20-0.80$ & $0.38^{* *}$ & $0.21-0.67$ & $0.45^{*}$ & $0.25-0.81$ \\
\hline$\geq 31$ minutes & $0.07^{* * *}$ & $0.03-0.20$ & $0.11^{* *}$ & $0.03-0.32$ & $0.23^{* * *}$ & $0.11-0.47$ & $0.40^{*}$ & $0.19-0.85$ \\
\hline \multicolumn{9}{|l|}{ Living in urban area } \\
\hline Rural & 1 & & 1 & & 1 & & 1 & \\
\hline Urban & $5.17^{* * *}$ & $2.14-12.48$ & $3.00^{* *}$ & $1.29-6.98$ & $5.72^{* * *}$ & $2.60-12.59$ & $4.84^{* * *}$ & $2.05-11.42$ \\
\hline \multicolumn{9}{|l|}{ Regions } \\
\hline Toronto & 1 & & 1 & & 1 & & 1 & \\
\hline North & $0.25^{*}$ & $0.08-0.77$ & $0.27^{*}$ & $0.10-0.70$ & $0.27^{*}$ & $0.09-0.86$ & $0.31^{*}$ & $0.10-0.98$ \\
\hline West & 0.50 & $0.24-1.04$ & 0.71 & $0.31-1.60$ & $0.43^{*}$ & 0.19-0.97 & 0.71 & $0.27-1.85$ \\
\hline East & $0.24^{* *}$ & $0.10-0.57$ & 0.43 & $0.15-1.22$ & $0.20^{* *}$ & $0.08-0.51$ & 0.40 & $0.12-1.28$ \\
\hline
\end{tabular}

*** $p<0.001 ; * * 0<0.01 ; * 0.05$

OR: odds ratio; $\mathrm{Cl}$ : confidence interval. Only the unadjusted and adjusted ORs and $\mathrm{Cls}$ of variables are included in the final models reported in this table.

school students with better perceived health were more likely to shift their travel mode to active $(\mathrm{OR}=2.97$; 95\%CI: 1.00-8.81). Elementary school students whose parents did not know where they were in their free time were more likely to shift their travel mode from passive to active $(\mathrm{OR}=1.87 ; 95 \% \mathrm{CI}: 1.00-3.49)$. For both elementary and secondary school students, there was no difference in the likelihood of mode shift between students who were physically active for five days per week or more and those who were active less than five days 
Table 4 Individual, behavioural, psycho-social, and environmental correlates of active school transports in secondary school students

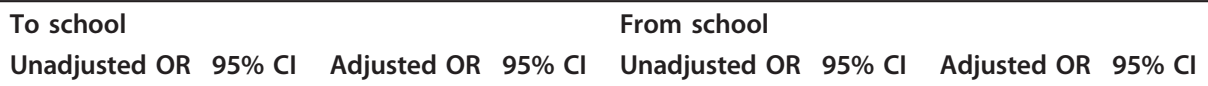

Socio- demographic

Grade

Grade 9

Grade 10

Grade 11

Grade 12

Sex

Boys

Girls

Weight status

Normal weight

Overweight/

Obese

Behavioural

MVPA

$$
\text { 0-4 day/wk }
$$

$\geq 5$ days/wk

Smoking in the past 12 months

Did not smoke

Occasional/regular smoker

Part-time job

Did not work outside home

1-5 hours/wk

$\geq 6$ hours/wk

\section{Psychological}

Decision-making on mode choice

Never/rarely/

sometimes

Often/always

Parents don't know where their children are in free time away from home

$$
\begin{aligned}
& \text { Always/usually } \\
& \text { Sometimes/seldom/never }
\end{aligned}
$$

\section{Environmental}

Travelled to/from school

$$
\begin{aligned}
& \text { 0-15 minutes } \\
& \text { 16-30 minutes } \\
& \geq 31 \text { minutes }
\end{aligned}
$$

\section{1}

$0.74^{*}$

$0.56-0.98 \quad 0.76$

$0.56-1.03$

0.72

$0.58^{* *}$

\section{$0.48-1.07 \quad 0.76$}

$0.41-0.81 \quad 0.65^{*}$

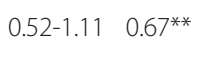

$0.45-0.93 \quad 0.55^{* * *}$

$0.47-0.97 \quad 0.80$

$0.41-0.75 \quad 0.62^{* *}$

0.57-1.11

$0.44-0.86$

ving in urban area

Rural

Urban

Regions

Toronto

North

West

East

Catholic school

No

Yes

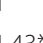

$1.43^{*}$

\section{1}

0.91

$0.24^{* * *}$

\section{$0.63-1.33 \quad 0.84$ \\ $0.14-0.40 \quad 0.23^{* * *}$}

0.94-1.97 
Table 4 Individual, behavioural, psycho-social, and environmental correlates of active school transports in secondary school students (Continued)

Changing school in the last five years

\begin{tabular}{|c|c|c|c|c|c|c|c|c|}
\hline No & 1 & & 1 & & 1 & \multicolumn{3}{|c|}{1} \\
\hline Yes & $1.39^{*}$ & $1.03-1.84$ & 1.19 & $0.87-1.63$ & $1.44^{* *}$ & $1.10-1.88$ & 1.35 & $0.99-1.82$ \\
\hline$g h$ & & & & & & & & \\
\hline No & 1 & & 1 & & 1 & & 1 & \\
\hline Yes & $1.37^{* *}$ & $1.10-1.72$ & $1.33^{*}$ & $1.05-1.70$ & $1.27^{*}$ & $1.02-1.58$ & 1.11 & $0.86-1.43$ \\
\hline
\end{tabular}

*** $p<0.001 ; * * 0.01 ; * 0<0.05$

OR: odds ratio; $\mathrm{Cl}$ : confidence interval. Only the unadjusted and adjusted ORs and Cls of variables are included in the final models reported in this table.

Table 5 Individual, behavioural, psycho-social, and environmental correlates of mode shift

\begin{tabular}{|c|c|c|c|c|c|c|c|c|}
\hline \multirow{3}{*}{ Socio- demographic } & \multicolumn{4}{|l|}{ Elementary } & \multicolumn{4}{|l|}{ Secondary } \\
\hline & $\begin{array}{l}\text { Unadjusted } \\
\text { OR }\end{array}$ & $95 \% \mathrm{Cl}$ & $\begin{array}{l}\text { Adjusted } \\
\text { OR }\end{array}$ & $95 \% \mathrm{Cl}$ & $\begin{array}{l}\text { Unadjusted } \\
\text { OR }\end{array}$ & $95 \% \mathrm{Cl}$ & $\begin{array}{l}\text { Adjusted } \\
\text { OR }\end{array}$ & $95 \% \mathrm{Cl}$ \\
\hline & & & & & & & & \\
\hline \multicolumn{9}{|l|}{ Grade } \\
\hline Grade 7 & 1 & & 1 & & - & - & - & - \\
\hline Grade 8 & 0.85 & $0.58-1.25$ & 0.83 & $0.51-1.37$ & - & - & - & - \\
\hline Grade 9 & - & - & - & - & 1 & & 1 & \\
\hline Grade 10 & - & - & - & - & 0.87 & $0.55-1.38$ & 0.69 & $0.40-1.16$ \\
\hline Grade 11 & - & - & - & - & 1.11 & $0.68-1.81$ & 0.93 & $0.50-1.73$ \\
\hline Grade 12 & - & - & - & - & 0.81 & $0.48-1.38$ & 0.80 & $0.42-1.52$ \\
\hline \multicolumn{9}{|l|}{ Sex } \\
\hline Boys & 1 & & 1 & & 1 & & 1 & \\
\hline Girls & 0.98 & $0.63-1.54$ & 0.83 & $0.44-1.58$ & 0.96 & $0.67-1.37$ & $0.70^{*}$ & $0.49-1.00$ \\
\hline \multicolumn{9}{|l|}{ Weight status } \\
\hline Normal weight & 1 & & 1 & & 1 & & 1 & \\
\hline Overweight/Obese & 1.67 & $0.97-2.87$ & 1.11 & $0.62-2.00$ & 0.91 & $0.62-1.32$ & 0.74 & $0.45-1.21$ \\
\hline \multicolumn{9}{|l|}{ Parent born abroad } \\
\hline Both/one parent born in Canada & 1 & & 1 & & & & & \\
\hline Both born abroad & $1.76^{*}$ & $1.05-2.98$ & 1.35 & $0.71-2.55$ & & & & \\
\hline \multicolumn{9}{|l|}{ Behavioural } \\
\hline \multicolumn{9}{|l|}{ MVPA } \\
\hline 0-4 day/wk & 1 & & 1 & & 1 & & 1 & \\
\hline$\geq 5$ days/wk & 0.79 & $0.43-1.44$ & 0.99 & $0.44-2.20$ & 1.05 & $0.72-1.55$ & 0.84 & $0.55-1.28$ \\
\hline \multicolumn{9}{|l|}{ Part-time job } \\
\hline Did not work outside home & - & & & & 1 & & 1 & \\
\hline 1-5 hours/wk & - & - & & & 0.73 & $0.42-1.29$ & 1.06 & $0.58-1.92$ \\
\hline$\geq 6$ hours/wk & - & - & & & $0.68^{*}$ & $0.47-0.99$ & 0.71 & $0.45-1.12$ \\
\hline \multicolumn{9}{|l|}{ Psychological } \\
\hline \multicolumn{9}{|l|}{ Perceived physical health } \\
\hline Fair/poor & 1 & & 1 & & - & & & \\
\hline Excellent/very good/good & $2.86^{* *}$ & $1.42-5.76$ & $2.97^{*}$ & $1.00-8.81$ & - & - & & \\
\hline \multicolumn{9}{|l|}{ Decision-making on mode choice } \\
\hline Never/rarely/sometimes & 1 & & 1 & & 1 & & 1 & \\
\hline Often/always & $3.00^{* * *}$ & $1.81-4.96$ & $2.43^{* * *}$ & $1.23-4.80$ & $2.29^{* * *}$ & $1.64-3.20$ & $2.42^{* * *}$ & $1.61-3.63$ \\
\hline \multicolumn{9}{|l|}{$\begin{array}{l}\text { Parents don't know where their } \\
\text { children } \\
\text { are in free time away from home }\end{array}$} \\
\hline Always/usually & 1 & & 1 & & & & & \\
\hline Sometimes/seldom/never & $2.64^{* *}$ & $1.46-4.77$ & $1.87^{*}$ & $1.00-3.49$ & & & & \\
\hline
\end{tabular}


Table 5 Individual, behavioural, psycho-social, and environmental correlates of mode shift (Continued)

\begin{tabular}{|c|c|c|c|c|c|c|c|c|}
\hline \multicolumn{9}{|l|}{ Environmental } \\
\hline \multicolumn{9}{|l|}{ Travelled to school } \\
\hline 0-15 minutes & 1 & & 1 & & 1 & & 1 & \\
\hline 16-30 minutes & $0.32^{*}$ & $0.11-0.94$ & $0.11^{* * *}$ & $0.03-0.40$ & $0.38^{* *}$ & $0.21-0.67$ & $0.16^{* * *}$ & $0.09-0.30$ \\
\hline$\geq 31$ minutes & $0.32^{*}$ & $0.11-0.95$ & $0.07^{* * *}$ & $0.02-0.29$ & $0.10^{* * *}$ & $0.03-0.27$ & $0.03^{* * *}$ & $0.01-0.10$ \\
\hline \multicolumn{9}{|l|}{ Travelled from school } \\
\hline 0-15 minutes & - & & & & 1 & & 1 & \\
\hline 16-30 minutes & - & - & & & $1.79^{* *}$ & $1.23-2.60$ & $4.32^{* * *}$ & $2.82-6.60$ \\
\hline$\geq 31$ minutes & - & - & & & $1.87^{* *}$ & $1.23-2.85$ & $10.49^{* * *}$ & $\begin{array}{l}6.44- \\
17.09\end{array}$ \\
\hline \multicolumn{9}{|l|}{ Living in urban area } \\
\hline Rural & 1 & & 1 & & 1 & & 1 & \\
\hline Urban & $3.79^{*}$ & $\begin{array}{l}1.14- \\
12.60\end{array}$ & $3.58^{*}$ & $\begin{array}{l}1.00- \\
12.90\end{array}$ & $5.60^{* *}$ & $\begin{array}{l}1.97- \\
15.89\end{array}$ & $3.24^{*}$ & $1.18-8.85$ \\
\hline \multicolumn{9}{|l|}{ Regions } \\
\hline Toronto & 1 & & 1 & & - & & & \\
\hline North & 0.52 & $0.17-1.59$ & 0.65 & $0.19-2.21$ & - & - & & \\
\hline West & 0.66 & $0.27-1.60$ & 0.85 & $0.29-2.48$ & - & - & & \\
\hline East & $0.26^{* *}$ & $0.10-0.66$ & 0.42 & $0.15-1.19$ & - & - & & \\
\hline \multicolumn{9}{|c|}{ Changing school in the last five years } \\
\hline No & - & & & & 1 & & 1 & \\
\hline Yes & - & - & & & $1.48^{*}$ & $1.04-2.10$ & 1.43 & $0.96-2.10$ \\
\hline
\end{tabular}

*** $p<0.001 ; * * 0<0.01 ; * 0.05$

OR: odds ratio; $\mathrm{Cl}$ : confidence interval. The unadjusted and adjusted ORs and $\mathrm{Cls}$ of variables only included in the final models are reported in this table.

per week $\left(\mathrm{OR}_{\text {ele }}=1.11\right.$ and $95 \% \mathrm{CI}: 0.62-2.00$ and $\mathrm{OR}_{\text {sec }}$ $=0.74 ; 95 \%$ CI: 0.45-1.21).

\section{Discussion}

This study examined i) the prevalence and correlates of active transport to and from school separately and ii) the correlates of mode shift from passive in the morning to active in the afternoon. In terms of the first purpose, the overall prevalence of walking/biking to and from school was $23 \%$ and $32 \%$, respectively, for secondary school students and correspondingly $38 \%$ and $47 \%$ for elementary school students which is higher than that typically reported in the USA $[12,18,19,30,31]$, similar to Australia [32] and New Zealand [33] but lower than European countries [34-36]. The overall prevalence is also consistent with Canadian literature $[4,7,8]$. The prevalence of active school transport also varied across regions. In the present study, the highest prevalence was found in Toronto. This is perhaps not unexpected given the proliferation of neighbourhood schools within neighbourhoods established throughout the $19^{\text {th }}$ century, the pre-automobile era. Such neighbourhoods would be characterised by a gridded street network and diverse and highly dense land use that facilitates non-motorised travel modes.

There was a higher prevalence of walking/biking either to or from school found for elementary school students than for secondary school students. Elementary schools may be located closer to students' homes, in our data, elementary school students had significantly shorter travel times than secondary school students (analysis not shown). Different correlates of active school transport were also found across elementary and secondary school students. In secondary school students, not working a part-time job, being male, and being physically active were positively correlated with active school transport whereas higher parental education, having a car(s), and poorer perceived health were negatively associated with active school transport in elementary school students.

To the best of our knowledge, the addition of decision making as a correlate has not been assessed before. This is an important correlate of active school transport in this sample. This supports the hypothesis of Panter et al. [17] that parents, the key decision makers, may be influenced by children's opinions when making a travel mode choice. Being involved in the decision making process on school travel mode may reflect both independent mobility and a positive attitude towards walking/biking to school which have been suggested to increase the likelihood of active school transport $[14,15,37,38]$. These data provide an interesting direction for interventions in actively engaging students as advocates for active modes of school transport. Child and youth involvement in school travel decision making may also be influenced by parental concern about safety issues and their trust in the spatial and other capabilities 
of children and youth as they navigate through neighbourhoods. Future studies should identify the factors (e. g., personal factors such as motivation for walking and attitudinal factors, such as parental attitudes towards walking and whether their neighbourhood is suitable for walking [e.g., their preference on place of residence]), that may facilitate child and youth involvement in school travel decision-making.

\section{Shift from motorized modes in the morning to active in the afternoon}

This is the first study specifically examining the correlates of mode shift from motorized alternatives in the morning to active in the afternoon. Approximately $10 \%$ of both elementary and secondary school students were mode shifters. This represents a sizeable proportion of students that may be an interesting target for understanding how to intervene on travel practices to encourage a larger share of students to take active modes for at least one part of the daily school trip. Living in an urban area, having an input into the decision making process, and having a shorter travel time to school were associated with active school travel in the morning and in the afternoon. Additionally, these variables were also associated with mode shift for both elementary and secondary school students.

The mode shift may be partially explained by parent's schedules and resource accessibility. Elementary school students with mothers who commuted to work in the morning were less likely to walk/bike to school, suggesting that a parent's temporal constraints and desire for convenience affect school travel mode choice [39]. In the afternoon, working parents may not be available to pick children up after school [40], leaving these children and youth with a requirement to find an alternative way to get home. Walking may be feasible for short trips along enabling infrastructures (well-connected street system with signalized intersections), and when they are permitted and prefer to do so. For example, in our sample, more students living in urban areas shifted their travel mode than in rural areas $(17.6 \%$ vs. $5.9 \%$ and $17.3 \%$ vs. $1.8 \%$ for elementary and secondary school students, correspondingly, p-value $<0.001$ ). Similarly, $20 \%$ of elementary and secondary school students being driven to school in 0-15 minutes walked back home whereas about $5 \%$ of students who were driven to school in 15 minutes or more shifted their mode in the afternoon ( $\mathrm{p}$ value $<0.001)$. Future studies should further examine the psychosocial (e.g., attitudes towards active commuting to school); household (e.g., parents' scheduling and travel mode to work); and environmental characteristics associated with the mode shifting behaviour reported here.
The present study shows the importance of examining mode shift as this is a group of students demonstrating different travel behaviours at different times of the school day. Focusing on mode shift raises the consideration as to whether interventions might be more effective by targeting either the a.m. or p.m. periods. Mode shifters were more likely to live within walking distance from school. Promoting active school transport in the morning may be more feasible in these mode shifters than those being driven both ways because, for example, parents or other caregivers are already accustomed to allowing their children to take an unescorted trip home in the afternoon.

\section{Limitations}

The nature of cross-sectional study makes causal inference impossible. Our findings solely relied on selfreport. Accelerometer may measure active school transport and physical activity more accurately. Substantial missing data on selected variables was found in both elementary and secondary school students; however, included and excluded subjects were comparable in terms of sex, grade and region. The strengths of the present study include a representative sample of Canadian students at a provincial level and analysing morning and afternoon school trips separately demonstrating the variation across time particularly in secondary school students.

Given that distance is the strongest and consistent correlate of active school transport [20], the inclusion of this variable in the analyses would have been informative. However, in this dataset, self-reported distance was not reported nor did we have access to the home and school location of respondents. Time was used as an indicator of the generalized cost of a particular travel mode but the inclusion of time in the specified models would have been strengthened if we had information on the travel times for each alternative transport mode.

\section{Implications}

The spatial, temporal and age-related variations in AST highlight the need for school-specific travel plans rather than 'one size fits all' interventions in promoting active school transport. Engaging children and youth in school transport decision-making may be an important and under-examined process for influencing school transport as well as overall physical activity. A significant proportion of children and youth can be described as mode shifters in moving to active modes of transport in the afternoon, and this natural shift might be an opportunity for the targeting of future interventions; particularly interventions seeking to maximise opportunities for youth physical activity in the after-school period [41]. 
School transport considerations will be integral to the success of such interventions.

\section{Conclusions}

In summary, our findings demonstrate that the prevalence of active school transport varies across time and region. Similarly, the correlates of school transport vary across time and age groups. Future research examining school transport should continue to make the analytic distinction between the morning and afternoon trip, and control for the moderating effect of age and geography in predicting mode choice.

\section{List Of Abbreviations}

AST: Active school transport; CDC: Centers for Disease Control and Prevention; OSDUHS:Ontario Student Drug Use and Health Survey

\section{Acknowledgements and funding \\ This research was funded by the Built Environment, Obesity and Health Strategic Initiative of the Heart and Stroke Foundation and the Canadian Institutes of Health Research (CIHR). OSDUHS is funded in part by ongoing support from the Ontario Ministry of Health and Long Term Care. We would like to thank all of the schools and students that participated in the study and the Institute for Social Research at York University for assistance with the survey design and data collection.}

\section{Author details}

${ }^{1}$ Faculty of Physical Education \& Health, University of Toronto, 55 Harbord Street, Toronto, Ontario, M5S 2W6, Canada. ${ }^{2}$ Department of Geography, University of Toronto at Mississauga, 3359 Mississauga Road North, Mississauga, Ontario, L5L 1C6, Canada. ${ }^{3}$ Centre for Addiction and Mental Health, 250 College Street, Toronto, Ontario, M5S 2S1, Canada.

\section{Authors' contributions}

BYW analyzed and interpreted the data and developed the first draft of the manuscript. GF and RB contributed to the conception and the design of the study. HI contributed to the analysis of the data. All authors provided critical feedback during manuscript development. Each author has read and approved the final manuscript.

\section{Authors' information}

BYW is a doctoral student in the Faculty of Physical Education and Health, University of Toronto and is a CIHR/HSFC Fellow in Population Intervention for Chronic Disease Prevention. GF is an Associate Professor in Faculty of Physical Education and Health, University of Toronto. RB is an Assistant Professor in the Department of Geography, University of Toronto. HI was a research analyst with the Centre for Addiction and Mental Health (CAMH) at the time of this research.

\section{Competing interests}

The authors declare that they have no competing interests.

Received: 28 March 2011 Accepted: 3 August 2011 Published: 3 August 2011

\section{References}

1. Tremblay MS, Shields M, Laviolette M, Craig CL, Janssen I, Gorber SC: Fitness of Canadian children and youth: Results from the 2007-2009 Canadian Health Measures Survey. Statistics Canada Health Reports 2010, 21:1.

2. Faulkner GEJ, Buliung RN, Flora PK, Fusco C: Active school transport, physical activity levels and body weight of children and youth: a systematic review. Prev Med 2009, 48:3-8.

3. Sirard JR, Slater ME: Walking and bicycling to school: A review. AJLM 2008 , 1559827608320127.
4. Buliung RN, Mitra R, Faulkner G: Active school transportation in the Greater Toronto Area, Canada: an exploration of trends in space and time (1986-2006). Prev Med 2009, 48:507-512.

5. Larsen $K$, Gilliland J, Hess $P$, Tucker $P$, Irwin J, He M: The influence of the physical environment and sociodemographic characteristics on children's mode of travel to and from school. Am J Public Health 2009, 99:520-526.

6. Mitra R, Buliung RN, Roorda MJ: The built environment and school travel mode choice in Toronto, Canada. Transport Res Rec 2010.

7. Pabayo R, Gauvin L: Proportions of students who use various modes of transportation to and from school in a representative population-based sample of children and adolescents, 1999. Prev Med 2008, 46:63-66.

8. Robertson-Wilson JE, Leatherdale ST, Wong SL: Social-ecological correlates of active commuting to school among high school students. J Adolescent Health 2008, 42:486-495.

9. Mitra R, Buliung RN, Faulkner G: Spatial clustering and the temporal mobility of walking school trips in the Greater Toronto Area, Canada. Health Place 2010.

10. Heurlin-Norinder M: Children, environment and independent mobility. In Evolving Environmental Ideals - Changing Way of Life, Values and Design Practices (14th IAPS Conference). Edited by: Gray M. Stockholm, Sweden; 1996:314-323.

11. Page A, Cooper A, Griew P, Jago R: Independent mobility, perceptions of the built environment and children's participation in play, active travel and structured exercise and sport: the PEACH Project. Int I Beh Nut Phys Act 2010, 7:17.

12. Evenson KR, Huston SL, McMillen BJ, Bors P, Ward DS: Statewide prevalence and correlates of walking and bicycling to school. Arch Pediat Adol Med 2003, 157:887-892.

13. Babey SH, Hastert TA, Huang W, Brown ER: Sociodemographic, family, and environmental factors associated with active commuting to school among US adolescents. J Public Health Pol 2009, 30(Suppl 1):S203-220.

14. Wen LM, Fry D, Rissel C, Dirkis H, Balafas A, Merom D: Factors associated with children being driven to school: implications for walk to school programs. Health Educ Res 2008, 23:325-334.

15. Merom D, Tudor-Locke C, Bauman A, Rissel C: Active commuting to school among NSW primary school children: implications for public health. Health Place 2006, 12:678-687.

16. DiGuiseppi C, Roberts I, Li L, Allen D: Determinants of car travel on daily journeys to school: cross sectional survey of primary school children. BMJ 1998, 316:1426-1428.

17. Panter JR, Jones AP, Van Sluijs EM: Environmental determinants of active travel in youth: A review and framework for future research. Int I Beh Nut Phys Act 2008, 5:34.

18. Beck LF, Greenspan Al: Why don't more children walk to school? J Safety Res 2008, 39:449-452.

19. Martin SL, Lee SM, Lowry R: National prevalence and correlates of walking and bicycling to school. Am J Prev Med 2007, 33:98-105.

20. Wong BY, Faulkner G, Buliung R: GIS measured environmental correlates of active school transport: A systematic review of 14 studies. International Journal of Behavioral Nutrition and Physical Activity 2011, 8:39.

21. Loucaides CA, Jago R, Theophanous M: Prevalence and correlates of active traveling to school among adolescents in Cyprus. Central European Journal of Public Health 2010, 18:151-156.

22. Cohen J: Statistical power analysis for the behavioral sciences New York: Academic Press; 1977, Revised edn.

23. Miller KE, Barnes GM, Melnick MJ: Gender and racial/ethnic differences in predicting adolescent sexual risk: athletic participation versus exercise. J Health Soc Behav 2002, 43:436-450.

24. Wheaton B, Clarke P: Space meets time: integrating temporal and contextual influences on mental health in early adulthood. ASR 2003, 68:680-706.

25. Faulkner G, Adlaf EM, Irving HM, Allison KR, Dwyer J: School disconnectedness: Identifying adolescents at risk in Ontario, Canada. J School Health 2009, 79:312-318.

26. Cole TJ, Bellizzi MC, Flegal KM, Dietz WH: Establishing a standard definition for child overweight and obesity worldwide: international survey. BMJ 2000, 320:1240-.

27. Are there special recommendations for young people?. [http://www.cdc. gov/nccdphp/dnpa/physical/everyone/recommendations/children.htm]. 
28. American Academy of Pediatrics: Children, adolescents, and television Pediatrics 2001, 107:423-426.

29. Faulkner G, Richichi V, Buliung R, Fusco C, Moola F: What's "quickest and easiest?": Parent decision making about school trip mode. International Journal of Behavioral Nutrition and Physical Activity 2010, 7:1-11.

30. Centers for Disease C, Prevention: Barriers to children walking to or from school-United States, 2004. MMWR 2005, 54:949-952.

31. Bungum TJ, Lounsbery M, Moonie S, Gast J: Prevalence and correlates of walking and biking to school among adolescents. $J$ Commun Health 2009, 34:129-134.

32. Booth ML, Okely AD, Denney-Wilson E, Hardy LL, Dobbins T, Wen L-M, Rissel C: Characteristics of travel to and from school among adolescents in NSW, Australia. J Paediatr Child H 2007, 43:755-761.

33. Yelavich S, Towns C, Burt R, Chow K, Donohue R, Sani HSH, Taylor K, Gray A, Eberhart-Phillips J, Reeder Al: Walking to school: Frequency and predictors among primary school children in Dunedin, New Zealand. New Zeal Med J 2008, 121:51-58.

34. Chillon P, Ortega FB, Ruiz JR, Perez IJ, Martin-Matillas M, Valtuena J, GomezMartinez S, Redondo C, Rey-Lopez JP, Castillo MJ, et al: Socio-economic factors and active commuting to school in urban Spanish adolescents: the AVENA study. Eur J Public Health 2009, 19:470-476.

35. Landsberg B, Plachta-Danielzik S, Much D, Johannsen M, Lange D, Muller MJ: Associations between active commuting to school, fat mass and lifestyle factors in adolescents: the Kiel Obesity Prevention Study (KOPS). Eur J Clin Nut 2008, 62:739-747.

36. Sjolie AN, Thuen F: School journeys and leisure activities in rural and urban adolescents in Norway. Health Promot Int 2002, 17:21-30.

37. McMillan TE: Urban form and a child's trip to school: The current literature and a framework for future research. J Plan Lit 2005, 19:440-456.

38. Heelan KA, Donnelly JE, Jacobsen DJ, Mayo MS, Washburn R, Greene L: Active commuting to and from school and BMI in elementary school children-preliminary data. Child: Care, Health \& Development 2005, 31:341-349.

39. McDonald NC: Household interactions and children's school travel: the effect of parental work patterns on walking and biking to school. Journal of Transport Geography 2008, 16:324-331.

40. Lee SM, Tudor-Locke C: Active versus passive commuting to school: What children say. Am J Health Studies 2005, 20:212-218.

41. Lytle LA, Murray DM, Evenson KR, Moody J, Pratt CA, Metcalfe L, ParraMedina D: Mediators affecting girls levels of physical activity outside of school: Findings from the trial of activity in adolescent girls. Ann Behav Med 2009, 38:124-136.

\section{Pre-publication history}

The pre-publication history for this paper can be accessed here: http://www.biomedcentral.com/1471-2458/11/618/prepub

doi:10.1186/1471-2458-11-618

Cite this article as: Wong et al: Mode shifting in school travel mode: examining the prevalence and correlates of active school transport in Ontario, Canada. BMC Public Health 2011 11:618.

\section{Submit your next manuscript to BioMed Central and take full advantage of:}

- Convenient online submission

- Thorough peer review

- No space constraints or color figure charges

- Immediate publication on acceptance

- Inclusion in PubMed, CAS, Scopus and Google Scholar

- Research which is freely available for redistribution

Submit your manuscript at www.biomedcentral.com/submit
Biomed Central 